\title{
Leaf Scorch of Purple-Leafed Plum and Sweetgum Dieback: Two New Diseases in Southern California Caused by Xylella fastidiosa Strains with Different Host Ranges
}

\author{
R. Hernandez-Martinez, Department of Microbiology, Center for Scientific Research and Higher Education of En- \\ senada (CICESE), Km 107 Ctra. Tijuana-Ensenada, 22860 Ensenada, Baja California, México; and D. A. Cooksey \\ and F. P. Wong, Department of Plant Pathology and Microbiology, University of California, Riverside 92521
}

\begin{abstract}
Hernandez-Martinez, R., Cooksey, D. A., and Wong, F. P. 2009. Leaf scorch of purple-leafed plum and sweetgum dieback: Two new diseases in Southern California caused by Xylella fastidiosa strains with different host ranges. Plant Dis. 93:1131-1138.

Sweetgum dieback and leaf scorch of purple-leafed plum are two new diseases of southern California landscape ornamentals. Samplings were conducted in 2003 and 2004 and 28 of 105 sweetgum (Liquidambar styraciflua) and 38 of 62 purple-leafed plum (Prunus cerasifera) plants tested positive for Xylella fastidiosa by enzyme linked immunosorbent assay. In all, 3 strains of $X$. fastidiosa were isolated from sweetgum and 13 from purple-leafed plum. All sweetgum strains and some purple-leafed plum strains grew on PW but not PD3 media. Strain PC045 from purple-leafed plum and strain LS022 from sweetgum were inoculated into their original hosts in addition to almond, oleander, and grapevine plants. Sweetgum plants also were inoculated with strains causing Pierce's disease, almond leaf scorch, and oleander leaf scorch. Strain PC045 caused symptoms in purple-leafed plum and almond plants within 6 months, and the pathogen was recovered from 93 and $100 \%$ of inoculated plants, respectively. Inoculation of grapevine and oleander plants with PC045 did not result in disease or recovery of the pathogen. In all, 5 of 25 sweetgum plants inoculated with LS022 showed symptoms after 9 months, and the pathogen was recovered from 3 of these plants. Inoculation of grapevine, oleander, and almond with LS022 resulted in no disease or recovery of the pathogen from the plants. A strain of Pierce's disease, a strain of oleander leaf scorch, and two strains from almond did not cause disease in sweetgum. These results confirm the role of $X$. fastidiosa strains as pathogens of purple-leafed plum and sweetgum, and that strains from sweetgum are unique in their host range.
\end{abstract}

Since the introduction of Homalodisca vitripennis (formerly $H$. coagulata), the glassy winged sharpshooter (GWSS), to southern California, there has been a marked increase in diseases of landscape ornamentals caused by the fastidious, xylem-limited bacterium, Xylella fastidiosa $(10,12)$. Two landscape ornamentals showing disease symptoms commonly associated with the presence of $X$. fastidiosa are sweetgum (Liquidambar styraciflua) and purple-leafed plum (Prunus cerasifera) (10). Both sweetgum and purple-leafed plum are widely planted, popular ornamentals in California. Sweetgum is a large deciduous tree indigenous to North America used for lumber and wood product production in the southeastern United States (8) as well as a shade tree in many urban areas. Purple-leafed plum is a small, deciduous tree that is often referred to as

Corresponding author: F. P. Wong

E-mail: frank.wong@ucr.edu

* The $\boldsymbol{e}$-Xtra logo stands for "electronic extra" and indicates that Figures 1 through 4 appear in color in the online edition.

Accepted for publication 30 June 2009.

doi:10.1094/PDIS-93-11-1131

(C) 2009 The American Phytopathological Society "ornamental plum" due to its horticultural characteristics that include attractive pink flowers and ruby red to reddish-purple foliage.

$X$. fastidiosa is a xylem-limited bacterium that is often vectored by insects from the sharpshooter subfamily (Cicadellinae) in the leafhopper family (Cicadellidae) (22), and both the bacterium and insect vectors are known to have very wide and diverse host ranges $(3,13,22)$. More than 15 different diseases of economic importance are caused by $X$. fastidiosa, including Pierce's disease of grape (5), almond leaf scorch (17), and citrus variegated chlorosis (2). The bacterium also affects ornamental landscape and shade tree plant species such as oleander, elm, oak, sycamore, maple, and mulberry $(14,21)$.

In 2003 and 2004, surveys were conducted in southern California landscapes as part of a larger project to identify and characterize strains of $X$. fastidiosa affecting new hosts $(10,12)$. Sweetgum and purple-leafed plum were identified early on as species potentially impacted negatively by the bacterium due to the high frequency of these plants showing symptoms in urban areas. In sweetgum, symptoms included foliar chlorosis and dieback, with the latter most obvious in spring when new shoots and leaves failed to emerge from dormant limbs (Fig. 1A and B). For purple-leafed plum, symptoms included a scorching of leaves and dieback symptoms similar to those of almond leaf scorch or plum leaf scald (Fig. 2A and B) $(4,17)$. In preliminary studies, $X$. fastidiosa was cultured from symptomatic sweetgum and purpleleafed plum, and phylogenetic analysis based on 16S-23S ribosomal DNA sequencing and random amplification of polymorphic DNA polymerase chain reaction (RAPD-PCR) showed that strains isolated from both hosts were similar to almond leaf scorch strains $(10,11)$, which have been proposed by Schaad et al. (19) as belonging to the subspecies $X$. fastidiosa subsp. multiplex, and distinct from strains causing Pierce's disease, oleander leaf scorch, or citrus variegated chlorosis.

The discovery of $X$. fastidiosa in both sweetgum and purple-leafed plum is a relatively new finding. The first report of $X$. fastidiosa in sweetgum in Kentucky was published in 1996 (9) and the pathogen was associated with sweetgum in California in 2004 (11). The first report of $X$. fastidiosa isolated from purple-leafed plum in California was made by HernandezMartinez et al. (11) in 2004. For both the sweetgum and purple-leafed plum strains collected and characterized in the previous study (10), the causal relationship between $X$. fastidiosa and the disease symptoms shown by sweetgum and purple-leafed plum was not confirmed. Additionally, minor differences between strains suggested that those isolated from sweetgum and purple-leafed plum, although similar to those causing almond leaf scorch $(10,19)$, may have different pathogenicity characteristics or host ranges. The objectives of the present study were to (i) confirm the role of our field-isolated X. fastidiosa strains in causing diseases of sweetgum and purple-leafed plum and (ii) test the potential of these strains to infect oleander, grape, and almond.

\section{MATERIALS AND METHODS}

Collection of samples and isolation of bacteria. Sampling was performed in five urban neighborhoods located in Riverside, San Diego, Orange, Ventura, and San Bernardino Counties as a part of a larger survey to characterize and detect $X$. fastidiosa from landscape ornamentals in southern California (10). Sampling was conducted over several weeks, starting in June 2003 and April 2004 when symptoms of dieback 
and leaf scorch became apparent in landscape hosts in southern California. In this survey, shoots and young tissue from all landscape ornamental plants showing scorch or dieback symptoms from approximately $10-\mathrm{km}^{2}$ sampling areas were taken for testing, including a number from sweetgum and purple-leafed plum trees $(10,12)$. Tissue was tested for the presence of $X$. fastidiosa using a commercially available enzyme-linked immunosorbent assay (ELISA) testing kit (PathoScreen Kit DAS-ELISA; Agdia, Elkhart, IN). For each sample, approximately $0.2 \mathrm{~g}$ of petiole and midvein tissue was placed in $2 \mathrm{ml}$ of sample buffer in a mesh sample bag (Agdia) and macerated using a mortar. The resulting suspension $(100 \mu \mathrm{l})$ was loaded into antibody-coated wells as per the manufacturer's instructions. Tissue from healthy, glasshouse-grown oleander and grapevine was similarly prepared and used as negative controls. Color development was measured at $650 \mathrm{~nm}$ in a SpectraMax microplate Reader using the SoftMaxPro software (version 3.1.2; Molecular Devices Corp.). ELISA reactions in which the optical density at $650 \mathrm{~nm}$ reading was twice the negative controls were considered positive for $X$. fastidiosa.

Isolation and culture of $X$. fastidiosa was attempted from the remaining tissue of samples testing positive, using methods previously described by HernandezMartinez et al. (10,12). Briefly, 2- to 3-cm sections of leaf petioles and midveins were surface sterilized ( 2 min in $95 \%$ ethanol, 2 min in $1.05 \% \mathrm{NaClO}_{3}$ solution, then rinsed twice for $2 \mathrm{~min}$ in sterile-distilled water), sliced crosswise into 2- to 3-mm-wide sections in $100 \mu \mathrm{l}$ of sterile phosphatebuffered saline (PBS) buffer $(10 \mathrm{mM}$ phosphate buffer and $150 \mathrm{mM} \mathrm{NaCl}, \mathrm{pH}$ 7.4) using a razor blade, and allowed to macerate for $10 \mathrm{~min}$. Next, $45 \mu \mathrm{l}$ of the solution was spread onto sterile PD3 (6) or PW (7) growth media contained in 6-cmdiameter petri dishes (Fisher Scientific, Pittsburgh). In both media, agar was replaced with $0.8 \%$ of Gelrite (SigmaAldrich, St. Louis). Plates were incubated at $28^{\circ} \mathrm{C}$ and evaluated at $1,2,4$, and 6 weeks after plating. When bacterial colonies characteristic of $X$. fastidiosa were found, they were subcultured onto new PD3 or PW media. Although multiple colonies were sometimes cultured from a single plant sample, each of the strains used in this study was unique and obtained from a single host plant.

Some of the $X$. fastidiosa strains collected in 2003 from sweetgum and purpleleafed plum were used in other work and partially described by Hernandez-Martinez et al. (10). Other strains from almond, grapevine, and oleander used in this study were collected previously (Table 1).

Molecular identification of $X$. fastidiosa strains. $X$. fastidiosa-specific PCR, RAPD-PCR, and sequencing of $16 \mathrm{~S}-23 \mathrm{~S}$ rDNA were used to identify and characterize bacterial strains as described in our previous work $(10,12)$. Briefly, DNA was extracted from 7- to 14-day old bacterial colonies with a Qiagen DNeasy Tissue Kit (Qiagen Inc., Valencia, CA) and resuspended in Tris-EDTA $(10 \mathrm{mM}$ Tris- $\mathrm{HCl}$ and $1 \mathrm{mM}$ EDTA, pH. 7.4) to a final concentration of $50 \mathrm{ng} / \mu \mathrm{l}$. X. fastidiosaspecific PCR was performed with primers RST31 and RST33 (16) and visualized by agarose gel electrophoresis. RAPD-PCR was performed as described by HernandezMartinez et al. (10) using two 10-base primers: OP-AA-09 (AGATGGGCAG) and OP-AA-11 (ACCCGACCTG) (Kit AA; Operon Technologies, Inc., Alameda, CA). The 16S-23S rDNA sequence was amplified using primers G1 (5'-GAAGTCGTAACAAGG-3') and L1 (5'-CAAGGCATCCACCGT-3') and sequenced as described previously $(10,12)$. Comparison to known strains was performed using MEGA and PAUP v 4.0 for 16S-23S rDNA and RAPD data, respectively $(15,23)$.

Bacteria identified as $X$. fastidiosa were harvested from petri dishes and suspended in PW broth with $20 \%$ glycerol for longterm storage at $-80^{\circ} \mathrm{C}$ for preservation and use in future studies.

Mechanical inoculations. Sweetgum, purple-leafed plum, oleander, and almond plants were obtained from commercial nurseries in California and grapevine cuttings were from the Foundation Plant Service located at the University of California, Davis. Sweetgum trees were acquired as

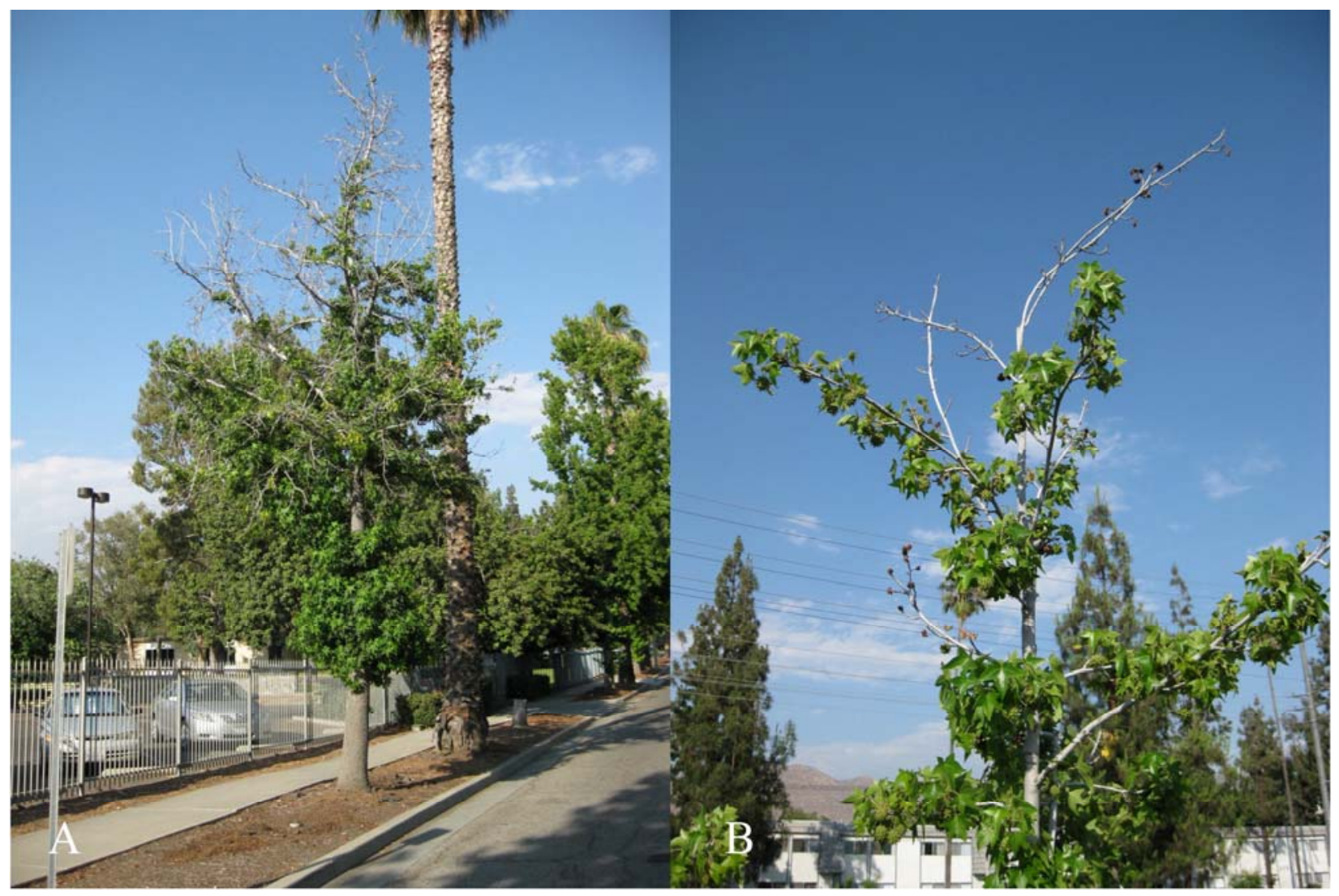

Fig. 1. A, Sweetgum in southern California showing dieback; B, typical dieback symptoms seen on branches. 
30-cm-tall seedlings potted in long, 1/4gallon pots. Purple-leafed plum plants (cv. Krauter Vesuvius) were acquired as 90-cmtall rooted cuttings. Almond plants (cv. Nonpareil) were acquired as 1-m-tall plants grafted on 'Nemaguard' rootstock. Oleander plants were obtained as small, liner-sized rooted cuttings in 5-by-5-by$20-\mathrm{cm}^{3}$ containers. Grapevines (Vitis vinifera cv. Pinot Noir) were obtained as dormant cuttings and rooted in sand for 6 weeks prior to transplanting. Sweetgum, oleander, and grapevines were planted in 1-gallon pots while purple-leafed plum and almond were planted in 3-gallon pots in a University of California soilless potting mix (a 1:1 mixture of sand:peat). All plants were tested for the presence of $X$. fastidiosa using ELISA as described above several weeks after transplanting and again a few days prior to inoculation, to confirm that they were pathogen free.

For inoculations, $X$. fastidiosa cultures were grown on PW medium for 7 days at $28^{\circ} \mathrm{C}$, except for strain LS022, which was grown for 20 days. All strains were suspended in an appropriate volume of PBS, $\mathrm{pH} 7.0$, to obtain a turbid bacterial suspension of approximately $1 \times 10^{7}$ cells $/ \mathrm{ml}$.

Plants were inoculated by pipetting a small drop of the bacterial suspension onto the main plant stem and probing the drop with a no. 1 insect pin (Indigo Instruments, Tonawanda, NY) until uptake of the drop was observed (13). Because of the similarity among strains obtained from the same host based on 16S-23S rDNA sequence and RAPD-PCR profiles (10) and limitations of glasshouse space, only one strain obtained from either sweetgum or purpleleafed plum was used.

Sweetgum strain LS022 was inoculated into 25 sweetgum plants to confirm pathogenicity in the host of origin and 15 plants each of almond, grapevine, and oleander to determine whether LS022 was pathogenic to these hosts. Sweetgum plants were also inoculated with previously characterized strains of $X$. fastidiosa to determine if those causing recognized diseases in other host species could infect sweetgum. Strains 276 and ALS035 were Dixon (1) and Pierce's disease types of almond leaf scorch strains, respectively, originating from almond; A05 was a Pierce's disease strain obtained from grapevine; and Riverside3 was an oleander leaf scorch strain obtained from oleander (Table 1). Each of these strains was inoculated into 10 sweetgum plants, as described.

Purple-leaf plum strain PC045 was inoculated into 15 plants each of purpleleafed plum, almond, grapevine, and oleander. In this experiment, reciprocal inoculations of purple-leaf plum with Pierce's disease, almond leaf scorch, or oleander leaf scorch strains were not performed.

Strains 276, ALS035, A05, and Riverside 3 were each inoculated into 15 plants of almond, grapevine, or oleander as posi- tive controls for the experiment to insure that the inoculation procedure was effective. Fifteen plants of each host species were inoculated only with PBS to serve as negative controls. Plants were placed in glasshouses at Agricultural Operations at the University of California-Riverside and maintained at approximately 20 to $30^{\circ} \mathrm{C}$ (minimum night time and maximum daytime temperatures, respectively) with ambient sunlight. To assess infection and colonization of the test plants, five petioles were cut randomly from each of the inocuscribed above at 3, 6, 9, and 12 months after inoculation. Attempts to culture $X$. fastidiosa from ELISA-positive and some control plants were performed on PW media as described above to corroborate ELISA results. Bacteria reisolated from lated plants and tested by ELISA as de-

inoculated plants were confirmed as $X$. fastidiosa by PCR amplification with the RST31/33 primer pair. Strain identification was performed by $16 \mathrm{~S}-23 \mathrm{~S}$ rDNA sequencing and RAPD-PCR analysis as described previously (10).

\section{RESULTS}

Isolation of $X$. fastidiosa from sweetgum trees and purple-leafed plum. In 2003 and 2004, in total, 105 sweetgum trees showing dieback symptoms were tested (Table 2). The number of symptomatic sweetgum plants varied by sampling location, with a minimum of 3 to a maximum of 37 samples collected from a targeted area. Samples testing positive by ELISA were highly variable, ranging from 0 to $60 \%$, with $27 \%$ of the 105 samples testing positive (Table 2). Only three

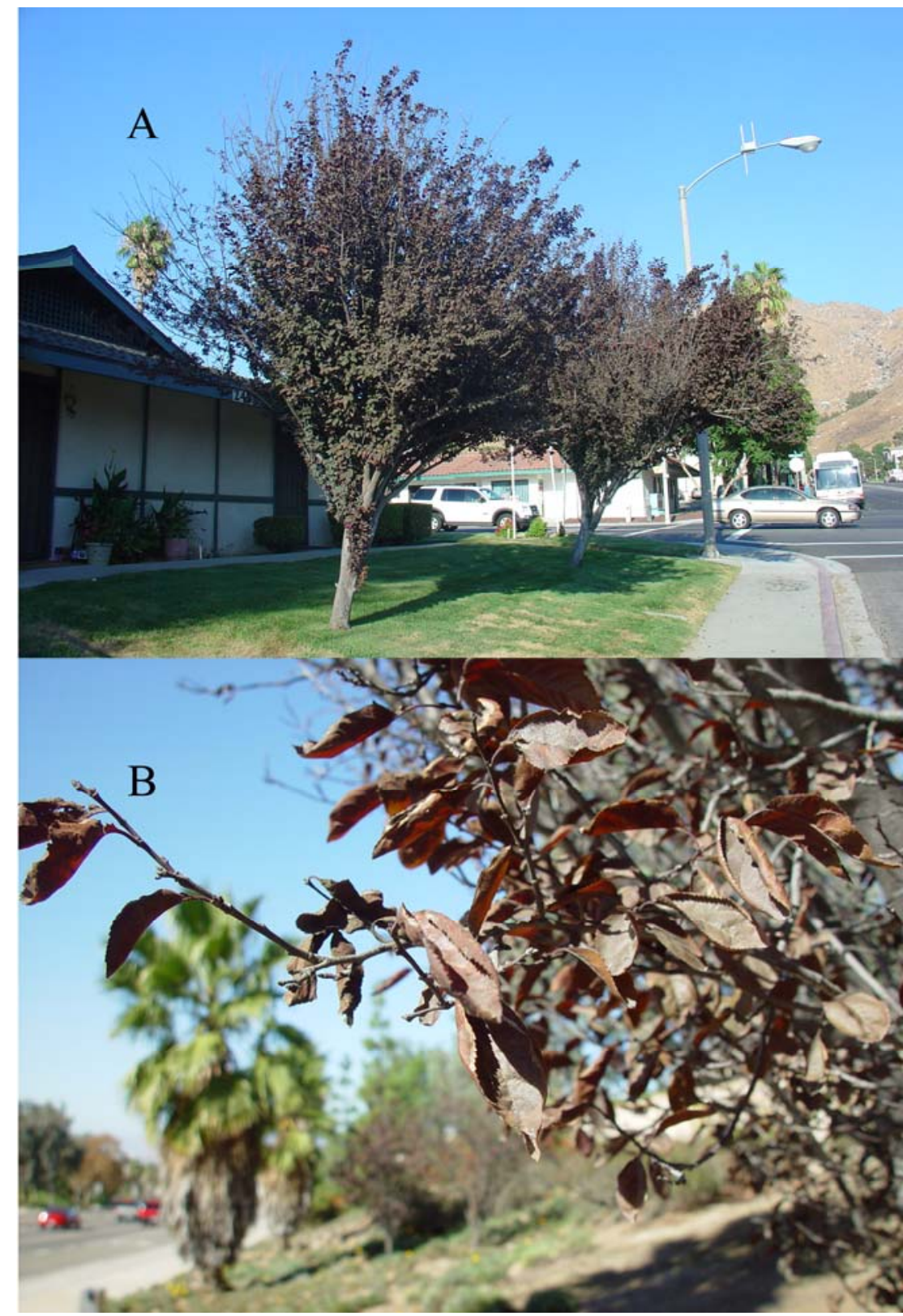

Fig. 2. A, Symptoms of dieback and leaf scorch on purple-leafed plum in southern California. B, Detailed view of scorch symptoms on foliage. 
strains were isolated from three different sweetgum trees in 2003 and none in 2004 (Table 1).

In all, 62 purple-leafed plum trees showing leaf scorch a were tested (Table 2). For the samples collected in 2003, 14 plants tested positive by ELISA and seven strains were isolated from individual symptomatic plants. In 2004, all 24 plants sampled were ELISA positive but only six strains were isolated. As with the sweetgum results, the number of symptomatic purple-leafed plum plants in a sampling area was variable (Table 2) but the percentage of plants testing positive by ELISA and frequency of successful isolation of $X$. fastidiosa from these plants was higher.
Characterization of strains. When DNA extracted from single colonies was PCR amplified with the $X$. fastidiosaspecific primers RST31 and RST33, a 733bp product was obtained from all of them, confirming their identity as $X$. fastidiosa (data not shown). Strains collected in 2003 (LS020, LS022, and LS043 from sweetgum and PC045, PC052, PC053, PC057, PC076, PC086, and PCAcll12 from purple-leafed plum) were determined from RAPD-PCR profiles and 16S-23S rDNA sequences (10) to be almond leaf scorch (non-Pierce's Disease type; 1) strains or belonging to the proposed $X$. fastidiosa subsp. multiplex group (19). Analysis of RAPD-PCR results and the $16 \mathrm{~S}-23 \mathrm{~S}$ rDNA

Table 1. Host sources of Xylella fastidiosa strains used in this study and their growth on PD3 and PW solid medium ${ }^{\mathrm{a}}$

\begin{tabular}{|c|c|c|c|c|}
\hline $\begin{array}{l}\text { Host of origin, } \\
\text { strain designation }\end{array}$ & $\begin{array}{c}\text { Geographic } \\
\text { origin }\end{array}$ & $\begin{array}{l}\text { Growth on } \\
\text { PD3 }\end{array}$ & $\begin{array}{l}\text { Growth on } \\
\text { PW }\end{array}$ & $\begin{array}{l}\text { Reference or } \\
\text { source }\end{array}$ \\
\hline \multicolumn{5}{|l|}{ Almond } \\
\hline 276 & Temecula & + & + & 3 \\
\hline ALS035 & San Bernardino & + & + & 10 \\
\hline \multicolumn{5}{|l|}{ Grapevine } \\
\hline A05 & Temecula & + & + & 3 \\
\hline \multicolumn{5}{|l|}{ Oleander } \\
\hline Riverside3 & Riverside & + & + & 12 \\
\hline \multicolumn{5}{|l|}{ Purple leafed-plum } \\
\hline PC045 & Riverside & + & + & 10 \\
\hline PC052 & Riverside & - & + & 10 \\
\hline PC053 & Riverside & - & + & 10 \\
\hline PC057 & Riverside & - & + & 10 \\
\hline PC076 & San Bernardino & + & + & 10 \\
\hline PC086 & Riverside & - & + & 10 \\
\hline PC1.1 & Riverside & + & + & This study \\
\hline PC1.2 & Riverside & + & + & This study \\
\hline PC1.3 & Riverside & + & + & This study \\
\hline PC1.4 & Riverside & + & + & This study \\
\hline PC13.1 & Riverside & + & + & This study \\
\hline PCAcll12 & Riverside & + & + & 10 \\
\hline PCSMF1.2 & Riverside & + & + & This study \\
\hline \multicolumn{5}{|l|}{ Sweetgum } \\
\hline LS020 & Riverside & - & + & 10 \\
\hline LS022 & Riverside & - & + & 10 \\
\hline LS043 & Riverside & - & + & 10 \\
\hline
\end{tabular}

a Symbols: + indicates growth on PD3 or PW solid medium and - indicates no growth after 6 weeks of incubation. sequence of strains collected in 2004 from purple-leafed plum strains PC1.1, PC1.2, PC1.3, PC1.4, PC13.1, and PCSMF1.2 showed that they were similar to those collected from purple-leafed plum in 2003 (data not shown).

Differences were observed in their ability to grow on PW and PD3 media. For some isolations, extracts obtained from field samples were plated onto the media and, on some plates, colonies were visible on both PW and PD3 media after 2 weeks of incubation. Extracts from some other plants produced colonies only on PW medium and only after 4 weeks of incubation. Purple-leafed plum strains PCAcll12, PC045, PC1.1, PC1.2, PC1.3, PC1.4, PCSMF1.2, PC076, and PC13.1 were derived from colonies which developed within 2 weeks on both PW and PD3 media, whereas strains PC057, PC086, $\mathrm{PC} 052$, and PC053 were obtained from those that developed after 4 weeks on PW medium (Table 1). Strains LS020, LS022, and LS043 from sweetgum were obtained only from sample extracts incubated on PW medium for 4 weeks. Subcultures from colonies that developed slowly on PW medium did not grow when transferred to new PD3 medium, and continued to grow slowly when transferred to new PW medium. Subcultures from colonies which developed on both PD3 and PW media grew equally well on either medium when transferred to new plates (data not shown). As a result, all strains were subsequently maintained on PW medium.

Mechanical inoculation and pathogenicity testing. Of 25 sweetgum plants mechanically inoculated with LS022, 5 showed dieback symptoms 6 months after inoculation (Table 3; Fig. 3A and B) and samples from all 5 plants gave positive results with ELISA at this time. X. fas tidiosa was recovered from only three of the five ELISA-positive plants with small bacterial colonies (three to five per plate) typical of $X$. fastidiosa observed around 40

Table 2. Plant survey results for symptomatic sweetgum and purple-leafed plum sampled in 2003 and 2004 and tested for the presence of Xylella fastidios $a^{\text {a }}$

\begin{tabular}{|c|c|c|c|c|c|c|}
\hline \multirow[b]{2}{*}{ Host, county surveyed $^{b}$} & \multicolumn{3}{|c|}{2003} & \multicolumn{3}{|c|}{2004} \\
\hline & No. infected & Percent & No. of strains & No. infected & Percent & No. of strains \\
\hline \multicolumn{7}{|l|}{ Sweetgum } \\
\hline Orange & $0 / 13$ & 0 & 0 & $0 / 3$ & 0 & 0 \\
\hline Riverside & $3 / 15$ & 20 & 0 & $0 / 10$ & 0 & 0 \\
\hline San Bernardino & $16 / 37$ & 43 & 3 & $9 / 15$ & 60 & 0 \\
\hline San Diego & $0 / 3$ & 0 & 0 & $0 / 3$ & 0 & 0 \\
\hline Ventura & $0 / 3$ & 0 & 0 & $0 / 3$ & 0 & 0 \\
\hline Total & $19 / 71$ & 27 & 3 & $9 / 34$ & 26 & 0 \\
\hline \multicolumn{7}{|l|}{ Purple-leafed plum } \\
\hline Orange & $2 / 7$ & 29 & 0 & $2 / 2$ & 100 & 0 \\
\hline Riverside & $6 / 18$ & 33 & 6 & $16 / 16$ & 100 & 6 \\
\hline San Bernardino & $4 / 5$ & 80 & 1 & $4 / 4$ & 100 & 0 \\
\hline San Diego & $2 / 3$ & 67 & 0 & $2 / 2$ & 100 & 0 \\
\hline Ventura & $0 / 5$ & 0 & 0 & $0 / 0$ & $\mathrm{n} / \mathrm{a}$ & $\mathrm{n} / \mathrm{a}$ \\
\hline Total & $14 / 38$ & 37 & 7 & $24 / 24$ & 100 & 6 \\
\hline
\end{tabular}

a Samples tested for Xylella spp. by enzyme-linked immunosorbent assay were considered positive if the optical density at $650 \mathrm{~nm}$ reading was twice the negative (noninfected plant tissue) controls. Data are presented as number of plants infected over number tested (No. infected); No. of strains $=$ number of strains obtained; $\mathrm{n} / \mathrm{a}=$ not applicable.

${ }^{\mathrm{b}}$ Surveys of plants showing scorch, dieback, or chlorosis made in areas of approximately $10 \mathrm{~km}^{2}$. 
to 50 days after incubation on PW medium only. Colonies were confirmed to be $X$. fastidiosa based on results from PCR using the RST31/33 primers, and sequence analysis of the 16S-23S rDNA and RAPDPCR profiles indicated that the recovered strains were identical to the LS022 strain (data not shown). The leaves of these five symptomatic plants began dropping after 6 months and these plants died before the 9month evaluation. The remaining 20 plants did not show symptoms and were negative when tested for $X$. fastidiosa by ELISA on the four evaluation dates. None of the grapevine, oleander, or almond plants inoculated with strain LS022 or any sweetgum plants inoculated with strains ALS035 or 276 from almond, A05 from grapevine, or Riverside3 from oleander were positive by ELISA when tested at the 3-, 6-, 9- and 12-month evaluation dates (Table 3 ).

All 15 purple-leafed plum plants inoculated with strain PC045 showed leaf scorch symptoms after 3 months (Table 3; Fig. 4A). At this time, all 15 of these plants tested positive by ELISA (Table 3 ) and $X$. fastidiosa was recovered from 14, with their identity confirmed by successful amplification of PCR product from cultured bacteria using RST31/33 PCR primers (data not shown). Scorched leaves on plum plants eventually abscised and most of the plants were dead by 7 months post inoculation.

All 15 almond plants inoculated with PC045 also showed typical almond leaf scorch symptoms after 6 months (Fig. 4C). All symptomatic almond plants were positive for $X$. fastidiosa by ELISA and $X$. fastidiosa was successfully recovered from samples taken at this time, with their identity confirmed by PCR of the isolated bacteria using the RST31/33 primer pair (data not shown). By 9 months, all almond plants inoculated with strain PC045 were dead.

In all cases, $X$. fastidiosa strains isolated from the 14 diseased purple-leafed plum and 15 diseased almond plants were identical to strain PC045 based on 16S-23S rDNA sequencing and RAPD-PCR analysis (data not shown).

In contrast, ELISA indicated that none of the oleander plants or grapevines inoculated with strain PC045 were infected and none showed disease symptoms over the 1year evaluation period. None of the PBSonly treated plants tested positive for $X$. fastidiosa by ELISA (Table 3) or showed symptom development (Fig. 4B and D).

Inoculation of strains A05, ALS035, 276, and Riverside 3 to the original hosts (grapevine, almond, and oleander, respectively) resulted in symptom development and ELISA-positive tests for all 15 plants used in each inoculation study. In grapevine, Pierce's disease symptoms were noticed around 2 months after inoculation and plants were dead 1 month later. In oleander, leaf scorch symptoms were noticed around 45 days after inoculation and plants were dead after 4 months. Almond plants inoculated with strain 276 showed leaf scorch disease 5 months after inoculation and remained alive up to a year whereas those inoculated with ALS035 showed symptoms 2 months after inoculation and were dead approximately 6 months after inoculation. The pathogen was recovered from almost all of the symptomatic, ELISA-positive plants (Table 3) and confirmed as $X$. fastidiosa by PCR using the RST31/33 primer pair and identified as the inoculum strain by $16 \mathrm{~S}$ $23 \mathrm{~S}$ rDNA sequence and RAPD-PCR profiles (data not shown).

\section{DISCUSSION}

In this study, we confirm that $X$. fastidiosa is a pathogen of purple-leafed plum and sweetgum in southern California. This is the first confirmation of disease caused by $X$. fastidiosa in purple-leafed plum and the first report in the western United States of disease in sweetgum caused by this pathogen. We propose "leaf scorch of purple-leafed plum" as the common name for the disease of $P$. cerasifera. Currently, the disease is common throughout many parts of southern California, although no reports have been made from areas north of Los Angeles and Ventura Counties. The development of disease in this host is not surprising considering the susceptibility of many Prunus spp. to $X$. fastidiosa. Interestingly, almond leaf scorch can be found commonly in almond in certain parts of California but does not appear to be a problem in commercial production of Prunus spp. such as plum, peach, and cherry. It was also confirmed in a previous study (10) that strains of $X$. fastidiosa isolated from purple-leafed plum were genetically different from those found affecting commercial plum ( $P$. salicina and $P$. domestica) production in Georgia.

Symptoms in sweetgum infected with $X$. fastidiosa also appear to be common in southern California landscapes. It is not known if California sweetgum strains are identical to strains causing leaf scorch in sweetgum in Kentucky (9). The most common and striking symptom seen on sweetgum in California was dieback (it occurred without the presence of leaf scorching or other foliar symptoms); therefore, we propose the common name "sweetgum dieback" for the disease. Whether or not the differences in symptoms reported from Kentucky and Califor-

Table 3. Evaluation of the host range of Xylella fastidiosa strains from purple-leafed plum and sweetgum

\begin{tabular}{|c|c|c|c|c|c|c|}
\hline \multirow[b]{2}{*}{$X$. fastidiosa strain $^{\mathbf{a}}$} & \multirow[b]{2}{*}{ Inoculum source plant } & \multirow[b]{2}{*}{ Test plant } & \multirow[b]{2}{*}{ No. inoculated } & \multicolumn{3}{|c|}{ No. of plants positive } \\
\hline & & & & Symptoms $^{b}$ & ELISA $^{c}$ & Culture $^{\mathrm{d}}$ \\
\hline \multirow[t]{4}{*}{ LS022 } & Sweetgum & Almond & 15 & 0 & 0 & $\mathrm{n} / \mathrm{a}$ \\
\hline & $\ldots$ & Grapevine & 15 & 0 & 0 & $\mathrm{n} / \mathrm{a}$ \\
\hline & $\ldots$ & Oleander & 15 & 0 & 0 & $\mathrm{n} / \mathrm{a}$ \\
\hline & & Sweetgum & 25 & 5 & 5 & 3 \\
\hline \multirow[t]{4}{*}{ PC045 } & Purple leafed-plum & Almond & 15 & 15 & 15 & 15 \\
\hline & $\ldots$ & Grapevine & 15 & 0 & 0 & $\mathrm{n} / \mathrm{a}$ \\
\hline & $\ldots$ & Oleander & 15 & 0 & 0 & $\mathrm{n} / \mathrm{a}$ \\
\hline & $\ldots$ & Purple leafed-plum & 15 & 15 & 15 & 14 \\
\hline \multirow[t]{2}{*}{276} & Almond & Almond & 15 & 15 & 15 & 14 \\
\hline & & Sweetgum & 10 & 0 & 0 & $\mathrm{n} / \mathrm{a}$ \\
\hline \multirow[t]{2}{*}{ ALS035 } & Almond & Almond & 15 & 15 & 15 & 14 \\
\hline & $\ldots$ & Sweetgum & 10 & 0 & 0 & $\mathrm{n} / \mathrm{a}$ \\
\hline \multirow[t]{2}{*}{ Riverside3 } & Oleander & Oleander & 15 & 15 & 15 & 15 \\
\hline & $\ldots$ & Sweetgum & 10 & 0 & 0 & $\mathrm{n} / \mathrm{a}$ \\
\hline \multirow[t]{2}{*}{ A05 } & Grapevine & Grapevine & 15 & 15 & 15 & 15 \\
\hline & $\ldots$ & Sweetgum & 10 & 0 & 0 & $\mathrm{n} / \mathrm{a}$ \\
\hline Negative control & PBS buffer & All hosts & 15 & 0 & 0 & $\mathrm{n} / \mathrm{a}$ \\
\hline
\end{tabular}

${ }^{a}$ Cultures were grown on solid PW medium and suspended in phosphate-buffered saline (PBS), pH 7.0, to obtain a turbid bacterial suspension of approximately $1 \times 10^{7}$ cells $/ \mathrm{ml}$.

${ }^{b}$ Number of plants showing chlorosis, scorch, or dieback symptoms during the 12-month evaluation period.

${ }^{\mathrm{c}}$ Number of plants testing positive with a commercial $X$. fastidiosa-specific enzyme-linked immunosorbent assay (ELISA) kit; results reflect tests performed 3 months to 1 year after inoculation.

${ }^{\mathrm{d}}$ Number of ELISA-positive experimentally inoculated plants from which the pathogen was successfully reisolated on PW media; $\mathrm{n} / \mathrm{a}=$ not applicable. 
nia are due to differences in the strains infecting sweetgum or in the different geographical locations remains to be determined.

The strains used to confirm Koch's postulates in purple-leafed plum and sweetgum were previously characterized as members of the proposed $X$. fastidiosa subsp. multiplex $(10,19)$ but their host range is different. Strain PC045 from purple-leafed plum caused disease in both purple-leaf plum and almond but not grapevine, suggesting that it is the same as previously documented almond leaf scorch strains that do not cause Pierce's disease in grapevine (1). On the other hand, LS022 isolated from sweetgum caused disease only in its original host. Also, sweetgum plants were not infected by strains which caused almond leaf scorch, Pierce's disease, or oleander leaf scorch, indicating that strains causing disease in sweetgum may be unique and cause a disease specific to sweetgum.

The experiments described here suggest that additional experiments should be performed to characterize further and elucidate the possible origins of the strains causing disease in purple-leaf plum and sweetgum. First, it does appear that disease in purple-leaf plum can be caused by strains originating in almond and viceversa. Because Pierce's disease strains can also cause disease in almond, it would be logical to test whether these strains can infect purple-leafed plum.. Second, only strain PC045 was used in the inoculation studies, and additional inoculations with strains that grow on PD3 should be made. These PW medium-specific strains may be more similar to the sweetgum strains and their ability to cause disease in sweetgum and other hosts (especially almond or other Prunus spp.) should be examined. Finally, the sweetgum strains should be inoculated into purple-leafed plum, as they do share similarities with some purple-leafed plum strains based on molecular studies (10) and media preference.

In this study, we found that purpleleafed plum and sweetgum strains grow on different media and at different rates. Sweetgum strains grew only on PW medium and developed very slowly compared with the other strains. Two strains were identified from purple-leafed plum: one easily cultured on PW and PD3 and one that did not grow on PD3 and grew slowly on PW, similar to the sweetgum strains. These characteristics are similar to those described for certain almond leaf scorch strains (1). The differences between these strains should be examined further with regard to differences in pathogenicity, virulence, and other characteristics. These results also suggest that success in isolating and culturing these pathogens may vary because some $X$. fastidiosa strains are more difficult to grow than others, and that the use of PD3 media only may be excluding the establishment of some strains in culture, with implications for the isolation of new $X$. fastidiosa strains from new hosts.

By comparing the $16 \mathrm{~S}-23 \mathrm{~S}$ rDNA sequence, prior work had shown purple-leaf plum and sweetgum strains to be very similar to known almond leaf scorch strains (e.g., the proposed X. fastidiosa subsp. multiplex group); however, some differences between purple-leafed plum and sweetgum strains were detected using RAPD analysis (10), separating strains from these two hosts into different subgroups within those characterized as $X$. fastidiosa subsp. multiplex. However, the RAPD-PCR performed in that study did not distinguish among purple-leafed plum isolates that could grow only on PW medium and those that could also grow on

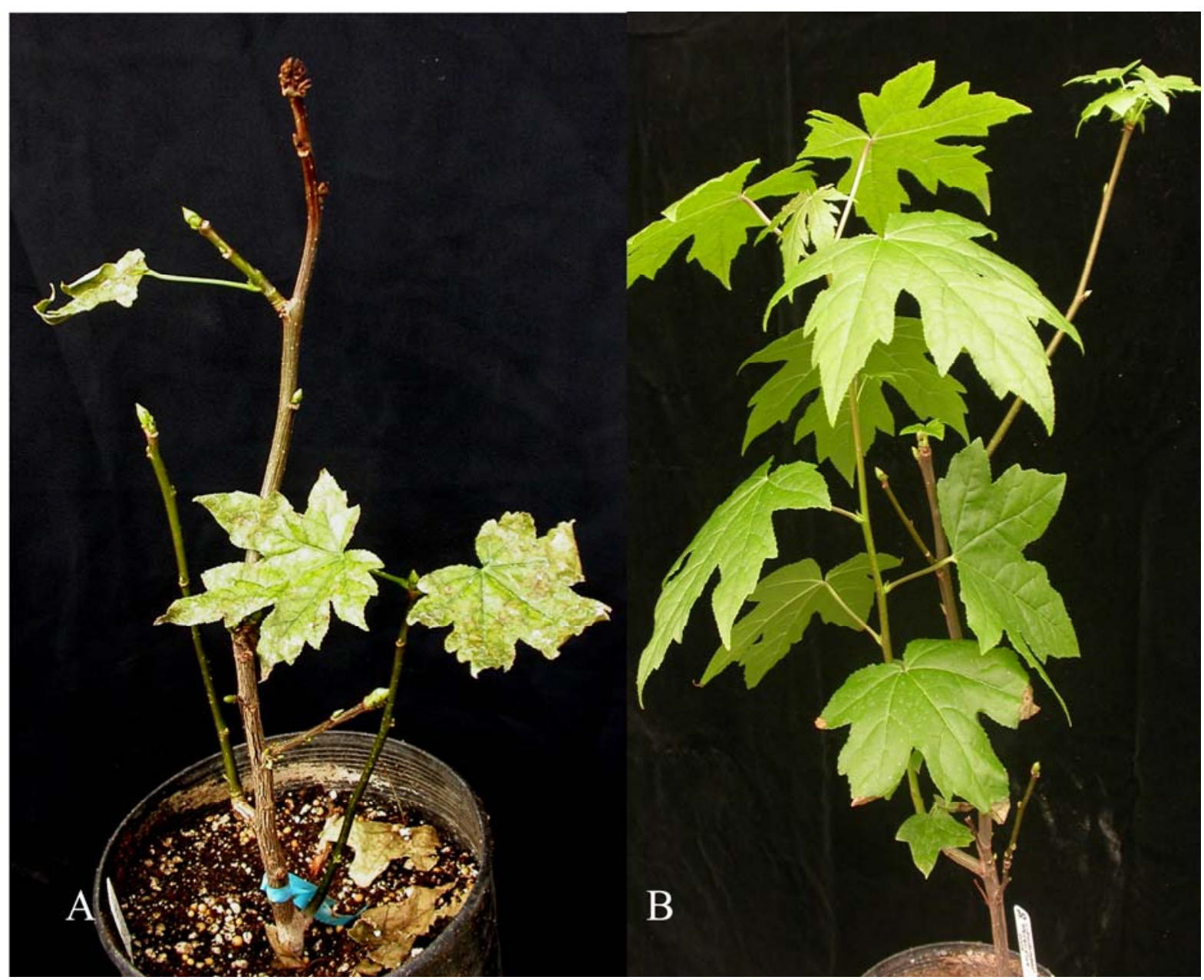

Fig. 3. A, Symptomatic plants 9 months after mechanical inoculation with Xylella fastidiosa strain LS022 isolated from sweetgum and B, a control plant inoculated with phosphate-buffered saline buffer. 
PD3. The differences in host range and culture medium preference support the presence of subgroups within the almond leaf scorch complex (which could be described as different pathovars within the proposed $X$. fastidiosa subsp. multiplex group). Differences among strains from the $X$. fastidiosa subsp. multiplex group were observed in previous studies. X. fastidiosa strains obtained from elm (Ulmus americana) and sycamore (Platanus occidentalis) were both characterized as $X$. fastidiosa subsp. multiplex (19) but did not produce reciprocal infections (20). The results presented in this study suggest that understanding the relationships of the different $X$. fastidiosa strains causing specific diseases in plants and constructing their taxonomy is far from simple and merits further research.

In this study, we encountered inconsistencies when correlating symptoms observed in the landscape, ELISA results, and the ability to isolate the pathogen from sweetgum. From 105 symptomatic sweetgum plants sampled over 2 years, only 28 gave ELISA-positive results and isolation from these plants yielded only three strains. Even plants in the landscape or grown in a glasshouse which gave strong positive ELISA values did not consistently yield culturable strains, even with multiple attempts. It is unknown if there are seasonal changes in bacterial titer or an un- even distribution of bacteria in planta which could affect isolation, or if some media other than PW are more suitable for isolation and culture. It is also possible that sweetgum tissue contains metabolites that are released when the plant tissue is macerated that inhibit the growth of $X$. fastidiosa. Studies are needed to determine the optimal plant tissues and times for sampling, as well as new media for the isolation of bacteria from sweetgum. Infection of sweet gum using mechanical inoculation was less successful than with the other hosts used in this study. Again, as seen in previous work $(10,12)$, it appears that mechanical inoculation using various strains and hosts may need optimization in each case and that the procedures developed for inoculation of grapevine may not be as effective in other hosts (1).

For both sweetgum and purple-leafed plum, it was also interesting to note that, of all of the areas sampled, the two warmer and drier inland locations (Riverside and San Bernardino locations) consistently had more symptomatic and ELISA-positive plants and were the most successful locations for culturing the pathogen from symptomatic trees. Potentially, the environmental conditions in these locations may be more favorable to the development of higher $X$. fastidiosa populations in planta. Although abiotic stress is generally associated with more severe symptoms caused by $X$. fastidiosa, the relationship between water availability, temperature, humidity, and other abiotic stresses such as air pollution and pathogen reproduction, survival, and movement should be further examined.

The presence of new $X$. fastidiosa diseases in California raises new and troubling questions for both urban landscapes and agricultural production in this area. Although established as diseases of shade and amenity trees in the eastern United States (21), the rise of $X$. fastidiosa as an issue in landscape ornamentals and trees in California is a recent development $(10,12,18)$ and it is possible that new diseases caused by this pathogen await to be discovered. The presence of these diseases in urban landscapes in southern California poses a special threat, because many landscape plant species in this area are best adapted to mesic habitats and only flourish in the xeric habitat of this area with supplemental irrigation. As water use for landscape irrigation conflicts with increased demand due to the growing population and potential climate changes decrease rainfall, the effects of decreased water availability can increase the severity of diseases caused by $X$. fastidiosa. Also, as urban environments in California encroach upon agricultural production areas, there is an increased chance of $X$. fastidiosa strains being vectored into areas of agricultural
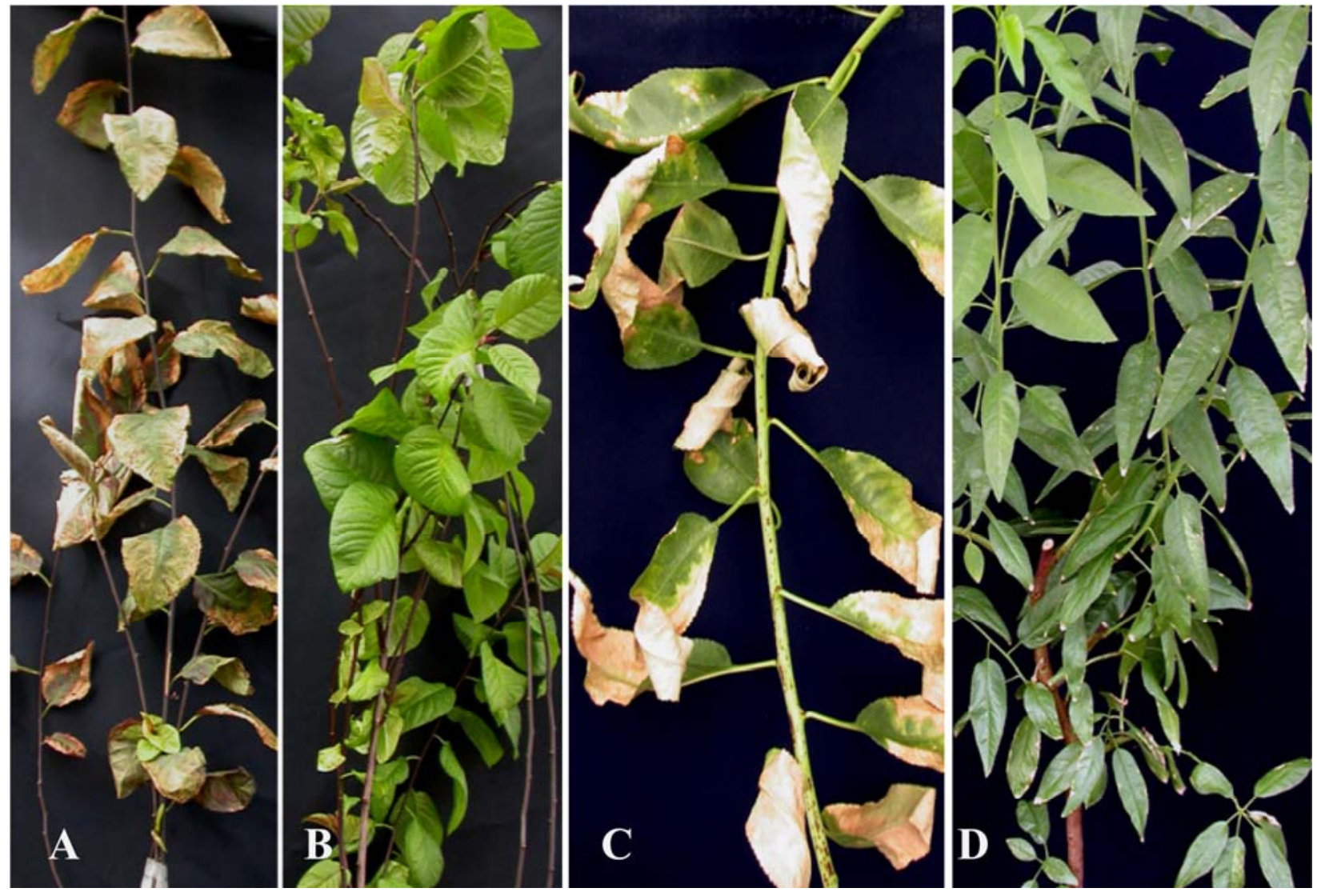

Fig. 4. A, Symptoms of leaf scorch in purple-leafed plum plants mechanically inoculated with Xylella fastidiosa strain PC045 compared with B, purpleleafed plum inoculated with PBS buffer. C, Almond leaf scorch symptoms produced by strain PC045 and D, almond inoculated with phosphate-buffered saline buffer. 
crops from landscape hosts. Under these circumstances, new $X$. fastidiosa diseases that develop in urban landscapes may foreshadow those that will occur in agricultural crops and, most certainly, $X$. fastidiosa will continue to be a problem for California urban landscape and agricultural production systems.

\section{ACKNOWLEDGMENTS}

Funding for this research was provided by the CDFA Pierce's Disease and Glassy-winged Sharpshooter Control Program and the University of California Agricultural Experiment Station. We thank K. de la Cerda and H. Azad for their help and contributions, and H. S. Costa and M. LuqueWilliams for their observations and insight.

\section{LITERATURE CITED}

1. Almeida, R. P. P., and Purcell, A. H. 2003. Biological traits of Xylella fastidiosa strains from grapes and almonds. Appl. Environ. Microbiol. 69:7447-7452.

2. Chang, C. J., Garnier, M., Zreik, L., Rossetti, V., and Bove, J. M. 1993. Culture and serological detection of the xylem-limited bacterium causing citrus variegated chlorosis and its identification as a strain of Xylella fastidiosa. Curr. Microbiol. 27:137-142.

3. Costa, H. S., Raetz, E., Pinckard, T. R., Gispert, C., Hernandez-Martinez, R., Dumenyo, C. K., and Cooksey., D. A. 2004. Plant hosts of Xylella fastidiosa in and near southern California vineyards. Plant Dis. 88:1255-1261.

4. Davis, M. J., French, W. J., and Schaad, N. W. 1981. Isolation and culture of the bacteria associated with phony peach disease and plum leaf scald. Phytopathology 71:869-870.

5. Davis, M. J., Purcell, A. H., and Thomson, S. V. 1978. Pierce's disease of grapevines: isolation of the causal bacterium. Science 199:75-77.

6. Davis, M. J., Purcell, A. H., and Thomson, S. V. 1980. Isolation media for the Pierce's disease bacterium. Phytopathology 70:425-429.

7. Davis, M. J., Raju, B. C., Brlansky, R. H., Lee, R. F., Timmer, L. W., Norris, R. C., and McCoy, R. E. 1983. Periwinkle wilt bacterium axenic culture pathogenicity and relationships to other gram-negative xylem inhabiting bacteria. Phytopathology 73:1510-1515.

8. Eyre, F. H. 1980. Forest Cover Types of the United States and Canada. Society of American Foresters, Washington, DC.

9. Hartman, J. R., Jarlfors, U. E., Fountain, W. M., and Thomas, R. 1996. First report of bacterial leaf scorch caused by Xylella fastidiosa on sugar maple and sweetgum. Plant Dis. 80:1302.

10. Hernandez-Martinez, R., de la Cerda, K. A., Costa, H. S., Cooksey, D. A., and Wong, F. P. 2007. Phylogenetic relationships of Xylella fastidiosa strains isolated from landscape ornamentals in southern California. Phytopathology 97:857-864.

11. Hernandez-Martinez, R., Dumenyo, C. K., Azad, H., S., Costa H. S., Wong, F. P., and Cooksey, D. A. 2004. Phylogenetic analyses of Xylella fastidiosa strains isolated from ornamental hosts. (Abstr.) Phytopathology 94:S152.

12. Hernandez-Martinez, R., Pinckard, T., Costa, H. S., Cooksey, D. A., and Wong, F. P. 2006. Discovery and characterization of Xylella fastidiosa strains in southern California causing mulberry leaf scorch. Plant Dis. 90:1143-1149.

13. Hill, B. L., and Purcell, A. H. 1995. Multiplication and movement of Xylella fastidiosa within grapevine and four other plants. Phytopathology 85:1368-1372.

14. Hopkins, D. L., and Purcell, A. H. 2002. Xylella fastidiosa: Cause of Pierce's disease of grapevine and other emergent diseases. Plant Dis. 86:1056-1066.

15. Kumar, S., Tamura, K., and Nei, M. 2003. MEGA3: An integrated software for molecular evolutionary genetic analysis and sequence alignment. Integr. Comp. Biol. 43.

16. Minsavage, G. V., Thompson, C. M., Hopkins, D. L., Leite, R. M. V. B. C., and Stall, R. E. 1994. Development of a polymerase chain reaction protocol for detection of Xylella fastidiosa in plant tissue. Phytopathology 84:456-461.

17. Mircetich, S. M., Lowe, S. K., Moller, W. J. and Nyland, G. 1976. Etiology of almond leaf scorch disease and transmission of the causal agent. Phytopathology 66:17-24.

18. Purcell, A. H., Saunders, S. R., Hendson, M., Grebus, M. E., and Henry, M. J. 1999. Causal role of Xylella fastidiosa in oleander leaf scorch disease. Phytopathology 89:53-58.

19. Schaad, N. W., Postnikova, E., Lacy, G., Fatmi, M. B., and Chang, C. J. 2004. Xylella fastidiosa subspecies: X. fastidiosa subsp. fastidiosa, subsp. multiplex subsp. nov., and $X$. fastidiosa subsp. pauca. Syst. Appl. Microbiol. 27:290-300.

20. Sherald, J. L. 1993. Pathogenicity of Xylella fastidiosa in American elm and failure of reciprocal transmission between strains from elm and sycamore. Plant Dis. 77:190-193.

21. Sherald, J. L., and Kostka, S. J. 1992. Bacterial leaf scorch of landscape trees caused by $X y$ lella fastidiosa. J. Arboric. 18:57-63.

22. Sorensen, J. T., and Gill, R. J. 1996. A range extension of Homalodisca coagulata (Say) (hemiptera, clypeorrhyncha, cicadellidae) to Southern California. Pan-Pac. Entomol. 72:160-161.

23. Swofford, D. L. 2002. PAUP*. Phylogenetic analysis using parsimony (*and other methods). Version 4.0b10. Sinauer Associates Sunderland, MA. 